\title{
Evaluation and optimization of DNA for RAPD analysis of Terminalia tomentosa
}

\author{
Mohd Rafi Wani ${ }^{* 1}$, Rajesh Rathore ${ }^{2}$, Javid Ahmad Malik ${ }^{3}$ \\ ${ }^{* 1}$ Jhelum Valley Forest Division, Baramulla, State Forest Department, Jammu and Kashmir,193103, India \\ ${ }^{2}$ District Silk Office, Janjgir-Champa,Chhattisgarh,495668,India \\ ${ }^{3}$ Department of Zoology, Guru Ghasidas University Koni, Chhattisgarh, 495009, India \\ Corresponding Author: rafiwani.009@gmail.com
}

Available online at: www.isroset.org

Received: 06/Dec/2018, Accepted: 10/Jan/2019, Online: 28/Feb/2019

\begin{abstract}
Forest tree species are more demanding than other plants to extract a pure and high quality of DNA for molecular genetics. A modified protocol for Terminalia tomentosa genomic DNA extraction was developed by introducing modification on Cetyl Trimethyl Ammonium Bromide (CTAB) method. The principle modification we involved in the present study are; PVP (Polyvinylpyrrolidone), column based purification step and copper acetate solution. Fresh leaves were collected from the tender shoots of mature trees of Terminalia tomentosa. The yield and the purity of genomic DNA was monitored by measuring optical density (O.D.) at A260 and A280 with a Nanodrop Spectrophotometer (ND2000). The highest amount of genomic DNA with the best quality was isolated from column based step in the CTAB extraction buffer. The yield of DNA by this modified method was approximately $100-153 \mu \mathrm{g}$ per $200 \mathrm{mg}$ of fresh leaf tissue. Both ratios were 2.1 and 1.8 respectively, indicating the absence of contaminating metabolites. The obtained DNA was then tested for suitability by random amplification of polymorphic DNA (RAPD)PCR analysis. Clear band pattern were observed for DNA isolated from four accessions of Terminalia tomentosa, collected from different geographical locations of Achanakmar Amarkantak Biosphere Reserve, Central India. The results clearly indicate the utility of DNA for genetic diversity analysis of this forest tree species.
\end{abstract}

Keywords: DNA extraction, CTAB method, quantity and purity, RAPD, Terminalia tomentosa

\section{INTRODUCTION}

Terminalia tomentosa Roxb is a large deciduous tree, 20$35 \mathrm{~m}$ high and $1 \mathrm{~m}$ in diameter belonging to family Combretaceae. The plant is common in the tropical forests of central India. It grows as an associate of Shorea robusta (Sal) in the forests of Achanakmar Amarkantak Biosphere reserve(AABR),Chhattisgarh. In the traditional medicinal system the tree has got very high economic importance, but still this tree is genetically uncharacterized. A good database of population genetic structure of this forest tree species can help tree breeder to exploit elite and genetically diverse germplasm for future improvement programmes. Thus monitoring of the genetic diversity of this tree in the natural forests of central India needs a concern for tree breeders. Our present knowledge about the assessment of genetic variation in forest trees within their natural habitat is based on genetic marker. The DNA markers are regarded as the best tools to accelerate breeding, genetic characterization in forest tree species.

For characterization of genetic diversity of Terminalia tomentosa, isolation of purified DNA proved to be a major bottleneck, as it has also been observed with other species like Terminalia arjuna [1], Vitis vinifera [2], Pinus radiata
[3], Tagetes minuta [4], Eucalyptus spp., Pinus spp. and Araucaria cunninghamii [5], Davidia involuctata [6], Anthurium andreanum [7], Artemisia dracunculus [8]. Higher amounts of secondary metabolites such as tannins, alkaloids, phenolics and terpenes makes the DNA isolation difficult in this tree species, as these secondary metabolites tend to copurify with DNA and interact irreversibly with proteins and nucleic acids [9], they may also interfere with DNA isolation, cloning, characterization [10] and inhibit the activity of DNA modifying enzymes [11].

A number of attempts were made to isolate the DNA of Terminalia tomentosa based on previously reported protocols but dirty yellow and viscous DNA was obtained which limited the genetic diversity studies of this tree species. The aim of this study is to establish a protocol for isolation of good quality of DNA from the leaves of Terminalia tomentosa which can be used for its population genetics.

\section{MATERIALS AND METHODS}

Plant material

Fresh juvenile leaves were collected from mature trees of Terminalia tomentosa in Achanakmar Amarkantak 
Biosphere Reserve (AABR) for DNA isolation. The sample was washed in double distilled water, then dried on a paper for 3-5 min and stored at $-25^{\circ} \mathrm{C}$ till DNA was isolated. The isolation of DNA was started after 3-5 days to avoid degradation.

\section{Isolation of DNA}

The commonly used DNA isolation method, developed by Doyle and Doyle [12] was tried in the beginning. Since the results proved to be unsatisfactory. Then we tried the protocols given by Krizman et al., [13] and Bokszczanin and Prazybyla, [14], but a good quality and quantity of DNA was not isolated. Finally the CTAB with column based purification method [1] was adapted and the significant results were obtained. The procedure of DNA isolation along with the modifications that were carried out and purification is reported here. The DNA isolated by CTAB method was dissolved in $1 \mathrm{ml}$ of sterile double distilled water (DDW) and purify using a column as follows

\section{Reagents:}

a) CTAB Buffer (1.4M NaCl, $100 \mathrm{mM}$ Tris- $\mathrm{HCl} \mathrm{pH}$ 8.0, 20mM EDTA pH 8.0, 2\% CTAB; added $\beta$ mercaptoethanol before use).

b) Chloroform:Isoamyl alcohol (24:1).

c) Ethanol 70 and $96 \%$

d) Isopropanol.

e) $\beta$-mercaptoethanol

f) TE buffer $(10 \mathrm{mM}$ Tris-HCl, $\mathrm{pH} 8.0 ; 1.0 \mathrm{mM}$ EDTA, pH 8.0)

\section{Protocol (Sarwat et al [1]).}

- Add $(700 \mu \mathrm{l}) \mathrm{ml}$ of 'Binding Solution' provided in the kit with the dissolved DNA and mix it thoroughly.

- Load the solution onto a red-o-ringed column fitted in a $2 \mathrm{ml}$ collection tube.

- Centrifuge the solution at $12000 \mathrm{rpm}$ for $1 \mathrm{~min}$ at room temperature.

- Discard the flow through liquid along with the collection tube and transfer the column to a fresh 2 ml collection tube.

- Add $500 \mathrm{ml}$ washing buffer (provided by the Kit) diluted with ethanol to the column and centrifuged as previously mentioned.

- Now discard the flow-through and wash the resultant DNA with $500 \mathrm{ml}$ of washing buffer to the column and centrifuge as above.

- Again discard the flow-through liquid, repeat the washing and centrifugation steps.

- Transfer the column (with DNA bound to the matrix) to a fresh collection tube.
- Add $100 \mathrm{ml}$ of elution buffer (preheated at $65^{\circ} \mathrm{C}$ ) to the column and incubated it at room temperature for $2 \mathrm{~min}$.

- Centrifuge the elute at 12,000 rpm for $1 \mathrm{~min}$.

- The resulting elute contains the DNA

- Store the elutes at $-20{ }^{\circ} \mathrm{C}$ till further processing.

- To test the effectiveness and efficiency of this protocol, we tried generation of RAPD markers.

\section{Quantification and visualization of DNA}

DNA was quantified by measuring optical density (O.D.) at A260 and A280 with a Nanodrop Spectrophotometer (ND2000). Samples were subjected to electrophoresis in $1 \times$ TBE buffer for 1 hour at $80 \mathrm{~V} .5 \mu \mathrm{l}$ of the isolated genomic DNA was loaded on $0.8 \%$ agarose gel stained with ethidium bromide to check DNA quality. The gels were photographed under a Gel documentation system .

Table 1. Comparison of yield and quality from various methods of DNA extraction.

\begin{tabular}{|c|c|c|c|c|}
\hline \multirow[b]{2}{*}{ S.NO } & \multirow[b]{2}{*}{ Method } & DNA & \multicolumn{2}{|c|}{ Genomic DNA } \\
\hline & & $\begin{array}{c}\text { yield } \\
(\mu \mathrm{g} \\
\text { DNA/g of } \\
\text { leaf } \\
\text { tissues })\end{array}$ & $\begin{array}{c}\text { Purity index } \\
\text { (A260/A230 } \\
\text { ratio) }\end{array}$ & $\begin{array}{c}\text { Purity index } \\
\text { (A260/A280 } \\
\text { ratio) }\end{array}$ \\
\hline 01 & Doyle and & $078 \pm 12.20$ & $1.17 \pm 0.032$ & $1.37 \pm 0.24$ \\
\hline 02 & Doyle(1987) & $092 \pm 08.44$ & $1.54 \pm 0.210$ & $1.70 \pm 0.05$ \\
\hline 03 & Krizman et & $101 \pm 05.89$ & $1.40 \pm 0.044$ & $1.57 \pm 0.03$ \\
\hline 04 & $\begin{array}{l}\text { al., (2006) } \\
\text { Bokszczanin } \\
\text { and } \\
\text { Prazybyla, } \\
\text { (2006) } \\
\text { CTAB with } \\
\text { column } \\
\text { based } \\
\text { purification } \\
\text { method }\end{array}$ & $153 \pm 07.24$ & $2.10 \pm 0.170$ & $1.86 \pm 0.11$ \\
\hline
\end{tabular}

All values are Mean \pm SE of triplicate determination.

\section{PCR analysis}

Approximately $50 \mathrm{ng}$ of genomic DNA were used as a template for PCR amplification The amplification was carried out in a $25 \mu \mathrm{l}$ reaction mixture containing $5 \mu \mathrm{l} 10 \times$ PCR reaction buffer, $0.2 \mathrm{mM}$ dNTPs, $10 \mathrm{pmol}$ (picomole) forward and reverse primers and $1 \mathrm{U}$ of Taq DNA polymerase. Cycling conditions consisted of an initial 2 min at $94^{\circ} \mathrm{C}$ followed by $1 \mathrm{~min}$ denaturing at $94^{\circ} \mathrm{C}, 1 \mathrm{~min}$ annealing at $56^{\circ} \mathrm{C}$ and 2 min elongation at $72^{\circ} \mathrm{C}$ repeated for 35 cycles and with 7 min extension at $72^{\circ} \mathrm{C}$.

\section{RAPD Analysis:}

RAPD markers were tested for Terminalia tomentosa species. RAPD reaction and procedures were carried out as described by Williams et al. 1990.The RAPD analysis was 
performed in a $15 \mu$ volume of reaction mixture containing 1 X Taq Polymerase buffer (with $25 \mathrm{mM} \mathrm{MgCl2}$ ), 0.6 units of Taq DNA Polymerase, $5 \mathrm{mM}$ dNTPs, $10 \mathrm{mM}$ of random decamer primer , and $15 \mathrm{ng}$ of total genomic DNA. Amplifications were carried out using a DNA thermal cycler (Mastercycler gradient, Biorad) with the following sequence: One cycle at $94^{\circ} \mathrm{C}$ for $2 \mathrm{~min}, 36^{\circ} \mathrm{C}$ for $2 \mathrm{~min}$ and extension at $72^{\circ} \mathrm{C}$ for $2 \mathrm{~min}$; 29 cycles of denaturation at $94^{\circ} \mathrm{C}$ for $1 \mathrm{~min}$, primer annealing at $36^{\circ} \mathrm{C}$ for $1 \mathrm{~min}$ and extension at $72^{\circ} \mathrm{C}$ for $1 \mathrm{~min}$; and final extension at $72^{\circ} \mathrm{C}$ for $10 \mathrm{~min}$. This reaction was stored at $8^{\circ} \mathrm{C}$ till loaded on gel. The products were size fractionated on $1.2 \%$ agarose gel and gel was photographed on Gel Documentation System.

In order to test the effectiveness and efficiency of obtained DNA for the genetic diversity analysis. Genotypes of $T$. tomentosa of diverse geographical locations from AABR were selected for suitability of RAPD marker system in genetic diversity analysis.

\section{RESULTS AND DISCUSSION}

A major goal of conservation biology is the preservation of genetic diversity in order to maintain the evolutionary potential of the species. The use of genetic data to determine evolutionary relationships between populations and species can make significant contribution to conservation. The genetic diversity assessment of forest tree species is a very difficult thing to undertake. The main problem being their long life cycle and the secondary metabolites synthesized by them. The molecular marker studies of forest tree species needs a large amount of quality genomic DNA, emphasizing screening of inexpensive, rapid and simple DNA extraction methods [15]. Besides, purification of genomic DNA in trees is difficult due to co-extraction of high quantities of tannins, polyphenols and polysaccharides [5]. Traditionally, molecular studies of forest tree species have used leaves as the source of DNA. A high endogenous levels of polysaccharides, phenolics and other organic constituents are found in the leaves of Terminalia tomentosa that interfere with the DNA isolation and purification. These secondary metabolities inhibits the activity of commonly used molecular biological enzymes [16], thus gives rise to the formation of gelatinous pellet [17] which interferes the purity of DNA. The presence of polyphenol makes the DNA resistant towards the restriction enzymes thus polyphenol copurify with DNA and interact irreversibly with proteins and nucleic acids $[9,18]$ and hinders the isolation of good quality and quantity DNA.

Keeping in mind the composition of the secondary metabolites in the leaves of Terminalia tomentosa we tried the earlier methods for the isolation of DNA like Doyle and Doyle [12], Rogers and Benedich [19] and Dellaporta et al. [20] but, they were found to be unsuccessful. We tried the CTAB method with little modifications. The modifications which were included for the extraction pure quality of genomic DNA are as; use of polyvinylpyrrolidone (PVP) [13], combining CTAB-based isolation with column-based purification [1] and including copper (II) acetate treatment [14].The leaves of Terminalia are rich in polyphenols and we tried PVP at different percentages(1,2 and 4 percentage ) according to the different authors $[21,22]$, but the quantity and the quality of DNA remain unsatisfactory and the obtained DNA was unable to generate a clear band pattern in RAPD marker system. The results were same for the Bokszczanin and Prazybyla, [14] and Doyle and Doyle [12] respectively. The only method which proved to be the most efficient for the extraction of good quantity and better quality of genomic DNA was by combining the CTAB DNA isolation with the column based purification [1]. The Table 1 clearly shows that the modification of column based purification modification on CTAB method yields a good quantity and pure quality of genomic DNA. In this method the genomic DNA first binds to the column thus helps washing of the impurities in the flow through liquid. Then the column bound DNA is washed twice with washing buffer and the pure genomic DNA is then eluted with elution buffer.

The modified CTAB with column based purification method produced the best optical density (O.D.) ratio at $\mathrm{A}_{260}$ and $\mathrm{A}_{280}$ with a Nanodrop Spectrophotometer, for the protein contamination $\left(\mathrm{A}_{260 / 280}\right)$ and carbohydrate contamination $\left(\mathrm{A}_{260 / 230}\right)$ (Table-1). To get a pure genomic DNA, the $\mathrm{A}_{260 / 280}$ ratio, which represent protein contamination, should be between 1.8 to 2.0 while the $\mathrm{A}_{260 / 230}$ ratio, which represent carbohydrate contamination, should be more than 2.0 [23]. Both ratios were 2.1 and 1.8 respectively, indicating the absence of contaminating metabolites. A good and highest quantity of genomic DNA (153 $\mu \mathrm{g}$ per 200mg) was extracted by CTAB column based purification method.

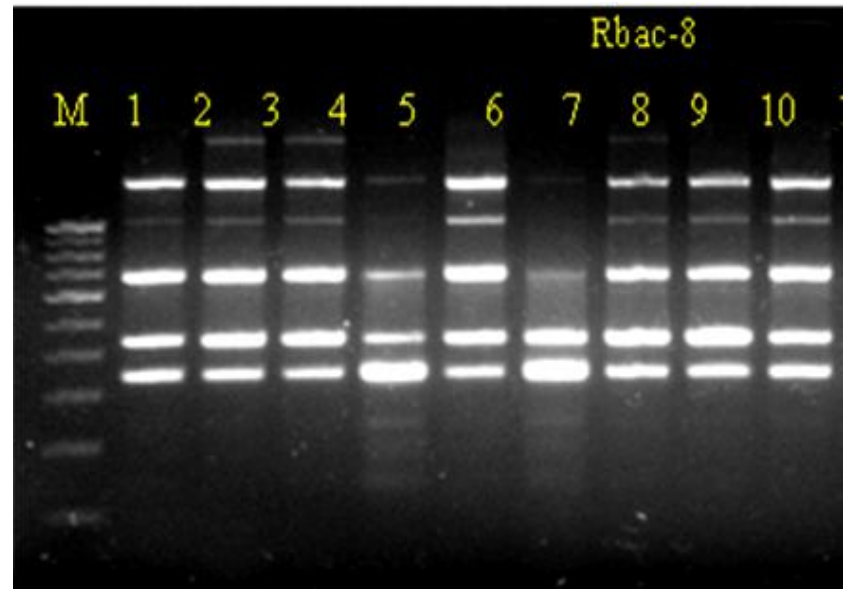

Fig 1: RAPD profile of Terminalia tomentosa generated by the primer Rbac-8 (5'ACCACCCACC3'). The samples were collected from different parts Achanakmar Amarkantak Biosphere Reserve (as indicated above the lanes). 
To test the suitability of the extracted DNA was subjected to PCR based RAPD (Random amplified polymorphic DNA) analysis (Fig-1). The agarose gel band patterns (Figure 1) showed that the bands formed by DNA extraction using modified CTAB with column based purification method produced clear and scorable bands without any vertical drag, indicating that the DNA was intact. Thus the present study demonstrate that the CTAB with column based purification method yields highly purified DNA, which is transparent, non-sticky and has no visible RNA contamination when electrophoresed on agarose gel. We have thus established a reliable method for isolation of good quality DNA from Terminalia tomentosa, a problem tree material for DNA isolation, that is amenable PCR based analyses such as RAPD.

\section{REFERENCES}

[1] Sarwat M, Negi MS, Lakshmikumaran M, Tyagi AK, Das S, Srivastava PS. A standardized protocol for genomic DNA isolation from Terminalia arjuna for genetic diversity analysis. Electronic Journal of Biotechnology 9(1): 86-91,2006.

[2] Hanania U, Velcheva M, Sahar N, Perl A. An improved method for isolating high-quality DNA from Vitis vinifera nuclei. Plant Molecular Biology Reporter. 22(2): 173-177,2004.

[3] Crowley TM, Muralitharan MS, Stevenson TW. Isolating conifer DNA: a superior polysaccharide elimination method. Plant Molecular Biology Reporter. 21(1): 97a-97d,2003.

[4] Hills PN, Van SJ. An improved DNA extraction procedure for plant tissues with a high phenolic content. South African Journal of Botany. 68(4):549-550,2002.

[5] Shepherd M, Cross M, Stokoe RL, Scott LJ, Jones ME. Highthroughput DNA extraction from forest trees. Plant Molecular Biology Reporter. 20(4): 425a-425j, 2002.

[6] Li YX, Su ZX, Chen F. Rapid extraction of genomic DNA from leaves and bracts of dove tree (Davidia involucrata). Plant Molecular Biology Reporter. 20(2): 185a-185e, 2002.

[7] Buldewo S, Jaufeerally-Fakim YF. Isolation of clean and PCRamplifiable DNA from Anthurium andreanum. Plant Molecular Biology Reporter. 20(1): 71a-71g,2002.

[8] Pirttila AM, Hirsikorpi M, Kamarainen T, Jaakola L, Hohtola A. DNA isolation methods for medicinal and aromatic plants. Plant Molecular Biology Reporter. 19(3): 273a-273f,2001.

[9] Katterman FRH, Shattuck VI. An effective method of DNA isolation from the mature leaves of Gossypium species that contain large amounts of phenolics, terpeniodes and tannins. Preparative Biochemistry. 13: 347-359,1983.

[10] Bousquet J, Simon L, Lalonde M. DNA amplification from vegetative and sexual tissues of trees using polymerase chain reaction. Can. J. For. Res. 20: 254-257,1990.

[11] Pandey RN, Adams RP, Flournoy LE. Inhibition of random amplified polymorphic DNAs (RAPDs) by plant polysaccharides. Plant Mol. Biol. Rep., 14(1), 17-22,1996.

[12] Doyle JJ, Doyle JL. Isolation of plant DNA from fresh tissue. Focus, 12: 13-15, 1990.

[13] Krizman M, Baricevic D, Prosek M. Fast quantitative determination of volatile constituents in fennel by headspace-gas chromatography. Analytica Chimica Acta 557: 267-271,2006.

[14] Bokszczanin K, Prazybyla AA. Copper (II) acetate improves the quality of pear (Pyrus) DNA during extraction. Plant Mol. Biol. Rep., 24: 249a-249d,2006.
[15] Weishing K, Nybom H, Wolff K, Meyer W. DNA isolation and purification. In:DNA fingerprinting in plants and fungi, pp 44-59. CRC Press, Boca Raton, Florida,1995.

[16] Fang G, Hammer S, Grumet R. A quick and inexpensive method for removing polysaccharides from plant genomic DNA. Biotechniques, 13 (1): 52-54,1992.

[17] Sharma AD, Gill PK, Singh P. DNA isolation from dry and fresh samples of polysaccharide-rich plants. Plant Molecular Biology Reporter, 20(4): 415a-415f,2002.

[18] Loomis WD. Overcoming problems of phenolics and quinones in the isolation of plant enzymes and organelles. Methods in Enzymology, 31: 528-545,1974.

[19] Rogers SO, Benedich AJ. Extraction of DNA from milligram amounts of fresh, herbarium and mummified plant tissues. Plant Molecular Biology Report, 5(2): 69-76,1985.

[20] Dellaporta SL, Wood J, Hicks JB. A plant DNA miniprepration: version II. Plant Molecular Biology Report, 1: 19-21,1983.

[21] Khanuja SPS, Shasany AK, Darokar MP, Kumar S. Rapid isolation of DNA from dry and fresh samples of plants producing large amounts of secondary metabolites and essential oil. Plant Molecular Biology Reporter, 17(1): 74, 1999.

[22] Keb Llanes M, Gonzalez G, Chi-Manzanero B, Infante D. A rapid and simple method for small scale DNA extraction in Agavaceae and other tropical plants. Plant Molecular Biology Reporter, 20(3): 299a-299e, 2002.

[23] Sambrook J, Russel DW. Molecular cloning: a laboratory manual. Third Edition. Cold Spring Harbor Laboratory Press. New York,2001. 